University of Nebraska - Lincoln

DigitalCommons@University of Nebraska - Lincoln

Publications from USDA-ARS / UNL Faculty

U.S. Department of Agriculture: Agricultural

Research Service, Lincoln, Nebraska

January 1982

\title{
Root Development of Winter Wheat as Related to Tillage Practice in Western Nebraska
}

Wallace Wilhelm

University of Nebraska-Lincoln, wwilhelm1@unl.edu

L. N. Mielke

University of Nebraska-Lincoln

C. R. Fenster

University of Nebraska-Lincoln

Follow this and additional works at: https://digitalcommons.unl.edu/usdaarsfacpub

Part of the Agricultural Science Commons

Wilhelm, Wallace; Mielke, L. N.; and Fenster, C. R., "Root Development of Winter Wheat as Related to Tillage Practice in Western Nebraska" (1982). Publications from USDA-ARS / UNL Faculty. 133.

https://digitalcommons.unl.edu/usdaarsfacpub/133

This Article is brought to you for free and open access by the U.S. Department of Agriculture: Agricultural Research Service, Lincoln, Nebraska at DigitalCommons@University of Nebraska - Lincoln. It has been accepted for inclusion in Publications from USDA-ARS / UNL Faculty by an authorized administrator of DigitalCommons@University of Nebraska - Lincoln. 


\title{
Root Development of Winter Wheat as Related to Tillage Practice in Western Nebraska ${ }^{1}$
}

\author{
W. W. Wilhelm, L. N. Mielke, and C. R. Fenster ${ }^{2}$
}

\begin{abstract}
Tillage practices can influence crop root development. Root distributions were determined for wheat (Triticum aestivum L.) grown in a wheat-fallow rotation during the 1977-1978 winter wheat crop year on an Alliance silt loam (Aridic Argiustoll). The fallow tillage treatments were plow, subtillage, and chemical (no tillage). Each tillage treatment was split into subplots for $N$ application of 0 or $\mathbf{4 5}$ $\mathrm{kg} / \mathrm{ha}$.

Rooting density was determined by washing the roots in soil cores $7.6 \mathrm{~cm}$ in diam by $15 \mathrm{~cm}$ long extracted to depths of 90,105 , and $120 \mathrm{~cm}$ on 28 Mar., 2 May, and 8 June 1978, respectively. After root length was determined, roots were dried and weighed. Soil penetration resistance was determined with depth in the soil by inserting a penetrometer horizontally $4 \mathrm{~cm}$ into the soil at vertical intervals of $10 \mathrm{~cm}$ from the surface.

Root weight was greatest for the chemical treatment $\left(46 \mathrm{mg} / \mathrm{dm}^{3}\right)$ and least for the subtillage treatment $\left(26 \mathrm{mg} / \mathrm{dm}^{3}\right)$. Approximately $62 \%$ of the total root mass was in the upper $30 \mathrm{~cm}$ of soil with maximum rooting depth greater than $120 \mathrm{~cm}$ for all treatments by 8 June 1978. Root development was limited by the alluvial horizon at a depth of about 25 to $40 \mathrm{~cm}$. Visual observations also showed some root resistance by tillage shear plane at $10 \mathrm{~cm}$. Nitrogen fertilization did not significantly change the rooting pattern; however, the $\mathrm{N}$-by-tillage interaction for root weight was significant at the second sampling date-the subtillage treatment showed a positive response to added $\mathbf{N}$, while chemical and plow treatments showed a negative response. Wheat yields were not significantly influenced by fallow tillage or $\mathbf{N}$. This indicated that root development occurring above and below the resistant layer was sufficient to supply the plant with its water and mineral needs.
\end{abstract}

Additional index words: Root distribution, Root weight, Root length, Triticum aestivum L., No tillage.

$\mathrm{R}$ OoT system development of winter wheat (Triticum aestivum L.) has been studied under many conditions. Kmoch et al. (1957) found that, by the end of autumn, roots had developed to a depth of more than $90 \mathrm{~cm}$ in plots watered to 120 or $180 \mathrm{~cm}$, but only to a depth of $75 \mathrm{~cm}$ in plots watered to $60 \mathrm{~cm}$.
Nitrogen fertilization increased root weights at all moisture levels and at nearly all sampling depths. With favorable soil moisture conditions, maximum rooting depth was $396 \mathrm{~cm}$. Soil water depletion was measured to the 244-cm depth.

Lupton et al. (1974) studied root growth of several normal and semidwarf cultivars of winter wheat in England. Their findings suggested that soil and climatic conditions influenced rooting depth and distribution more than did genetic makeup of the plant material.

In recent years, fallow practices involving less tillage have become increasingly important in the Great Plains. Chemical fallow (Wicks and Smika, 1973) is gaining more acceptance by winter wheat growers as an alternative to conventional tillage-type fallow systems. There are theoretical advantages that suggest chemical fallow should improve wheat yields by: (1) increasing soil water storage (Greb et al., 1967; Smika and Wicks, 1968), and (2) reducing soil erosion (Fenster et al., 1958; Horner, 1960). The objective of our study was to determine how several fallow-tillage practices and $\mathrm{N}$ fertilization affected winter wheat root growth and distribution in the central Great Plains.

\section{MATERIALS AND METHODS}

The fallow-tillage practices evaluated in this study were plow, subtillage, and chemical (no tillage). The plots were established in 1969 in a wheat-fallow rotation at the High

\footnotetext{
'Contribution from the USDA, ARS in cooperation with the Nebraska Agric. Exp. Stn., Lincoln, NE. Published as Paper No. 6215, Journal Series, Nebraska Agric. Exp. Stn. Received 11 May 1981 .

${ }_{2}^{2}$ Plant physiologist and soil scientist, USDA, ARS, Univ. of Nebraska-Lincoln, Lincoln, NE 68583, and professor of agronomy, Univ. of Nebraska-Lincoln, Panhandle Station, Scottsbluff, NE 69361 , respectively.
} 
Table 1. Mean wheat root density of three fallow tillage practices [chemical (no tillage), plow, and subtillage] at three sampling dates during 1978.

\begin{tabular}{|c|c|c|c|c|}
\hline \multirow{2}{*}{$\begin{array}{l}\text { Tillage } \\
\text { practice }\end{array}$} & \multicolumn{4}{|c|}{ Sampling date } \\
\hline & 28 March & 2 May & 8 June & Mean \\
\hline & \multicolumn{4}{|c|}{$\longrightarrow$ root density $\left(\mathrm{mg} / \mathrm{dm}^{3}\right)$} \\
\hline $\begin{array}{l}\text { Chemical } \\
\text { Plow } \\
\text { Subtillage }\end{array}$ & $\begin{array}{c}12 \dagger \\
5 \\
9\end{array}$ & $\begin{array}{l}60 \\
36 \\
25\end{array}$ & $\begin{array}{l}62 \\
59 \\
44\end{array}$ & $\begin{array}{l}46 \neq \\
33 \\
26\end{array}$ \\
\hline
\end{tabular}

$\dagger$ L.S.D. (0.05) for tillage practice $\times$ sampling date $=11$.

$\ddagger$ L.S.D. $\{0.05\}$ for tillage practice $=9$.

Plains Agricultural Laboratory near Sidney, Nebr., on an Alliance silt loam (Aridic Argiustoll). Each main plot was split into subplots for $\mathrm{N}$ application of 0 or $45 \mathrm{~kg} / \mathrm{ha}$. After harvest in late July, no field operations were used until the primary tillage or chemical application occurred about 15 April. The plow treatment plots were moldboard plowed to a depth of $10 \mathrm{~cm}$; secondary tillage (field cultivation and rotary rod weeding) was used as needed to keep the soil free of weeds. On the subtillage treatment plots, primary tillage was done with a $1.5-\mathrm{m}$ " $V$ " sweep to a depth of 10 $\mathrm{cm}$; for secondary tillage, a rotary rod weeder was used as needed to control weeds. Successive tillage operations were done at decreasing depths. On the chemical plots, paraquat $\left(1,1^{\prime}\right.$-dimethyl-4,4'-bipyridinium ion), glyphosate $[N$-(phosphonomethyl) glycine], 2,4-D [(2,4-dichlorophenoxy) acetic acid], or dicamba $(3,6$-dichloro-o-anisic acid) were applied as needed to control weeds at the rates of $1.10,0.84,1.10$, and $0.28 \mathrm{~kg} / \mathrm{ha}$, respectively. Weeds were sprayed when they were 5 to $10 \mathrm{~cm}$ tall.

The winter wheat cultivar Centurk was planted with a deep-furrow drill about 15 September (1969-1978) in 30-cm rows at a rate of $50 \mathrm{~kg}$ seed/ha. Seeding depth was about $5 \mathrm{~cm}$. Phosphate fertilizer $(45 \mathrm{~kg} / \mathrm{ha})$ was applied at seeding time. The growing wheat in the plus $\mathrm{N}$ treatment was topdressed with $45 \mathrm{~kg} \mathrm{~N} / \mathrm{ha}$ as $\mathrm{NH}_{4} \mathrm{NO}_{3}$ during the first 2 weeks of April. The wheat crop was harvested mechanically in mid-July. Yield was determined by weighing the grain harvested from the entire plot area and corrected to $12 \%$ water content. A detailed description of the experimental site and the cultural practices was published by Fenster and Peterson (1979).

The experimental design was a randomized complete block with four replications and a split-plot arrangement of $\mathrm{N}$ fertilizer treatments. The whole plots (tillage treatment) were $8.5 \times 72.7 \mathrm{~m}$; subplots were $4.25 \times 72.7 \mathrm{~m}$.

Rainfall during the fallow period preceding planting in September 1977 (August 1976-August 1977) totaled $43.5 \mathrm{~cm}$, which was $6.2 \mathrm{~cm}$ below normal. Rainfall during the 1977-1978 cropping season (September 1977-July 1978) totaled 35.7 $\mathrm{cm}$, which was $4.3 \mathrm{~cm}$ below normal. The distribution of this rainfall was good in April and May, with $16.4 \mathrm{~cm}(4.0$ $\mathrm{cm}$ above normal); however, the June rainfall was $5.2 \mathrm{~cm}$ below normal.

Root samples were collected on 28 Mar., 2 May, and 8 June 1978 (during the fifth crop-fallow cycle), using a Giddings ${ }^{3}$ hydraulic soil sampler equipped with a $7.6-\mathrm{cm}$-diam $\times 120-\mathrm{cm}$ probe. Samples were taken midway between the rows in areas where there was no wheel traffic during planting in 1977. At each sampling date, cores were divided into 15-cm-long segments, placed in plastic bags, and stored at $4 \mathrm{C}$. Cores were extracted to depths of 90,105 , and $120 \mathrm{~cm}$ on the first, second, and third sampling dates, respectively.

\footnotetext{
${ }^{3}$ Mention of a trademark, proprietary product, or vendor does not constitute a guarantee or warranty of the product by the USDA and does not imply its approval to the exclusion of other products or vendors that may be suitable.
}

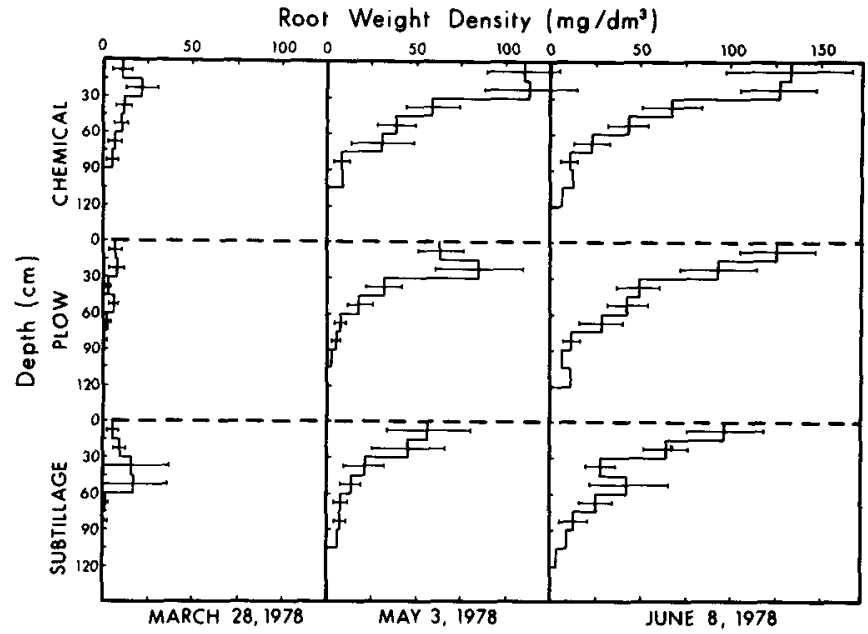

Fig. 1. Wheat rooting density $\left(\mathrm{mg} / \mathrm{dm}^{2}\right.$ of soil surface area) for the 0 to $30-\mathrm{cm}$ depth (a) and total depth of sampling (b) at three sampling dates in 1978 .

Individual soil cores were soaked 2 hours in a calcium metaphosphate (Calgon) solution and washed by hand through a 50-mesh sieve. Root material retained in the sieve was stored in a $50 \%(\mathrm{v} / \mathrm{v})$ aqueous solution of ethyl alcohol. Root lengths were determined with a Lambda 3000 leaf area meter calibrated with known lengths of cotton thread. Samples were later dried at $80 \mathrm{C}$ for 24 hours and weighed.

Using a Proctor penetrometer, we measured soil penetrometer resistance into the side wall of hand-dug pits in one replication. Before resistance measurements were made, about $2.5 \mathrm{~cm}$ of soil was removed from the pit wall by chipping with a knife tip. We determined penetrometer resistance by uniformly forcing the tip horizontally $4 \mathrm{~cm}$ into the soil. The average penetrometer resistance was determined from five readings taken at each $10-\mathrm{cm}$ increment to a depth of $120 \mathrm{~cm}$. Individual readings at each depth were separated horizontally by $10 \mathrm{~cm}$. The readings were taken on 8 June 1978.

Although data reported here is only for the 1978 cropping season, the tillage and $\mathrm{N}$ treatments were applied to the same plots in the manner described above from 1969-1978. A summary of grain yield and water storage data was published by Fenster and Peterson (1979).

\section{RESULTS AND DISCUSSION}

At the first sampling date ( $28 \mathrm{March}$ ), the root density averaged 12,5 , and $9 \mathrm{mg} / \mathrm{dm}^{3}$ in the upper $90 \mathrm{~cm}$ of soil for the chemical, plow, and subtillage treatments (Table 1). By the second sampling date (2 May), the average root density had increased 400,620 , and $178 \%$ for the chemical, plow, and subtillage treatments, respectively. The increases in root density between the second and third sampling date (8 June) were less $-5,64$, and $76 \%$ for the chemical, plow, and subtillage treatments, respectively. Approximately $60 \%$ of the total root mass was produced in the upper $30 \mathrm{~cm}$ of soil in all treatments.

The rate of growth of root systems for the three tillage treatments is shown in Fig. 1. For the surface $30 \mathrm{~cm}$ of soil, the chemical treatment showed greatest root density per unit soil surface area. The relative difference among the tillage treatments was consistent between the 0 to $30-\mathrm{cm}$ depth and the total rooting density to the maximum depth of sampling. The chem- 


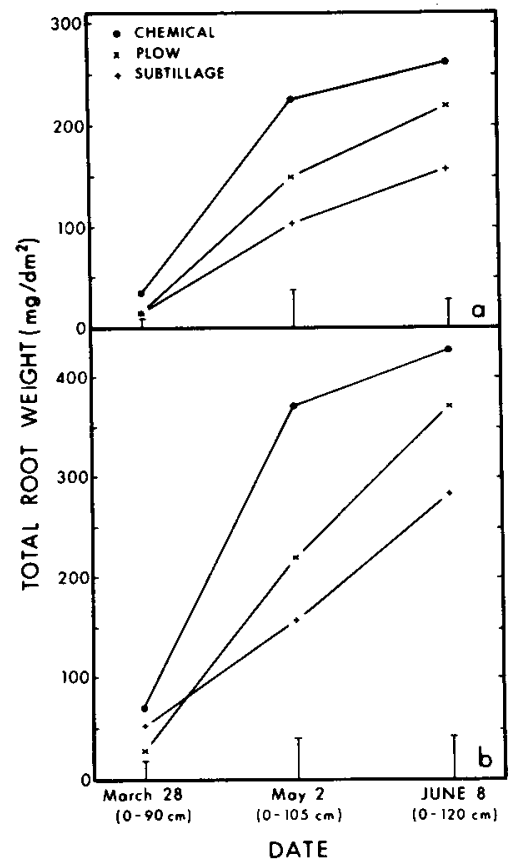

Fig. 2. Wheat root weight distribution $\left(\mathrm{mg} / \mathrm{dm}^{3}\right)$ with depth in the soil for three fallow practices.

ical treatment consistently had the greatest rooting density, while subtillage had the lowest.

Root development was resisted to the greatest degree at about the $40-\mathrm{cm}$ depth in all treatments. This layer coincides with a $B_{2} t$ horizon of illuviation at a depth of 25 to $40 \mathrm{~cm}$. Especially noticeable was the subsequent increase in rooting density below the $B_{2} t$ horizon in the subtillage treatment $(40 \mathrm{~cm}$, Fig. 2).

Penetrometer resistances (Fig. 3) also indicated the presence of a soil layer at $40 \mathrm{~cm}$ that would be expected to reduce root development. Taylor and Gardner (1963) reported a critical penetration resistance value of $29.0 \mathrm{~kg} / \mathrm{cm}^{2}$ above which no root penetration was observed in cotton (Gossypium hirsutum L.). They also found that the relationship between penetrometer resistance and root penetration was valid whether the increase in resistances was caused by increased bulk density or decreased soil water content. We observed a layer of soil with extremely high penetrometer resistance at $10 \mathrm{~cm}$ in the plow treatment. This depth corresponded to the depth of plowing, suggesting that the resistant layer probably represented a well-developed plow shear plane. The penetration resistance values suggested that root development in this layer might be reduced; however, no such decrease in root development was found at $10 \mathrm{~cm}$ (Fig. 2), especially on 2 May, when maximum root concentrations occurred in the 15 to $30-\mathrm{cm}$ layer. The method of sampling may have masked our ability to detect changes in rooting density associated with narrow layers of greater penetration resistance. Sampling all of the root tissue from $15-\mathrm{cm}$ segments did not allow detection of variations in rooting density within the segment.

Visual examination of the soil cores from all treatments at the time of sampling revealed natural fracturing along horizontal planes at various depths, with the most fracturing evident near the $10-\mathrm{cm}$ depth. The

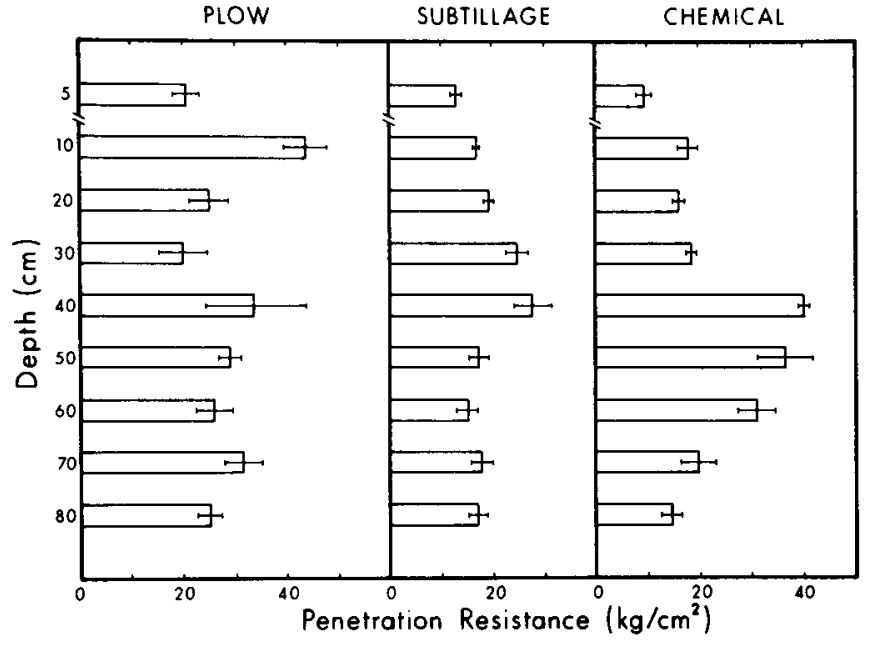

Fig. 3. Soil penetration resistance with depth in the soil for three fallow practices. Penetrometer was forced $4 \mathrm{~cm}$ horizontally into the soil at various depths.

soil interfaces at these fractures were lined with roots growing horizontally, suggesting less root resistance horizontally than vertically at this point. The Alliance soil has a well-defined vertical fracturing characteristic; as roots develop along the horizontal planes and encounter vertical fractures, downward growth resumes. Substantial root development was noted in insect and decaying root canals. These biological avenues also allow roots to traverse resistant soil layers.

The application of $\mathrm{N}$ had no significant effect on rooting pattern. The tillage by $\mathrm{N}$ interaction was significant at the second sampling where the chemical and plow treatments produced fewer roots when $\mathrm{N}$ was applied; however, the subtillage treatment produced more roots with applied $\mathbf{N}$. These overall root growth characteristics may have been associated with the effect of phytotoxic compounds (such as patulin) being produced by microbes decomposing partially incorporated residue typically found in the subtillage treatment (Ellis et al., 1977; Norstadt and McCalla, 1971). The numbers of Penicillium urticae Bainier (a patulin-producing organism) were less in plow and chemical than in the subtillage treatment (J. R. Ellis, microbiologist, USDA-ARS, Lincoln Nebr., personal communication).

Specific root length (root length/root weight) is a measure of the fineness of the root system. The larger the ratio of root length to root weight, the more fibrous the root system. In this study, the root systems were more fibrous at the first sampling date (28 March, specific root length $=69 \mathrm{~cm} / \mathrm{mg}$ ) than at the later sampling dates $(15 \mathrm{~cm} / \mathrm{mg}$ for both 2 May and 8 June sampling dates). Neither tillage, $\mathrm{N}$ treatment, sampling depth, nor their interactions significantly influenced specific root length.

Tillage and $\mathrm{N}$ treatment did not significantly influence wheat grain yields which averaged $3,300 \mathrm{~kg} / \mathrm{ha}$ in 1978. Fenster and Peterson (1979) reported only 1 year between 1969-1977 in which grain yield differed significantly $(P<0.05)$ among tillage treatments in this experiment. The lack of a significant yield reduction associated with the horizontal root growth observed at the plow layer interface implies that either 
roots in all treatments were impeded by this layer equally or that the root functions (supplying water and minerals) were not significantly impaired by root-resisting zones in the soil. The penetrometer resistance of the plow shear plane layer in the plow treatment was greatest, suggesting that roots were not impeded equally across tillage treatments. Therefore, it must be assumed that overall root functions were not significantly impaired by this relatively thin root-resisting zone (Taylor, 1971). Another explanation for the lack of yield response to various root densities may be that more roots were produced by the plant than were needed to adequately supply the plant's need for water and minerals (De Roo, 1968). If a sufficient root mass ultimately develops below the resistant layer, root functions in terms of plant growth, development, and grain yield may not be influenced. The possibilities of resisted root systems supplying a crop with adequate water and minerals would be greatest in years of sufficient soil water. Mild stress conditions with an unresisted root system may not reduce yield; however, with a resisted root system, mild stress may severely affect yields (Taylor, 1971).

The similar yields produced by plant communities having different rooting densities suggest that the activity of the root systems varied and that the relationship between above and below-ground plant parts was different among the tillage treatments. This indicates that further study is needed to examine the interrelationships among root growth, root activity, and crop yield.

\section{LITERATURE CITED}

1. DeRoo, H. C. 1968. Tillage and root growth. p. 339-358. In W. J. Whittington (ed.) Root growth. Butterworths, London. 2. Ellis, J. R., F. A. Norstadt, and T. M. McCalla. 1977. Patulin effects on wheat plants in field treatments. Plant Soil 47:679-686.

3. Fenster, C. R., F. L. Duley, and J. C. Swinbank. 1958. Questions and answers about stubble mulch. Nebr. Ext. Serv. Circ. 58123. 4 p.

4. — as compared to conventional tillage in a wheat-fallow system. Nebr. Agric. Exp. Stn. Res. Bull. 289.

5. Greb, B.W., D. E. Smika, and A. L. Black. 1967. Effect of straw mulch rate on soil water storage during summer fallow in the Great Plains. Soil Sci. Soc. Am. Proc. 31:556-559.

6. Horner, G. M. 1960. Effect of cropping systems on runoff, erosion, and wheat yields. Agron. J. 52:342-344.

7. Kmoch, H. G., R. E. Ramig, R. L. Fox, and F. E. Koehler. 1957. Root development of winter wheat as influenced by soil moisture and nitrogen fertilization. Agron. J, 49:20-25.

8. Lupton, F. G. H., R. H. Oliver, F. B. Ellis, B. T. Barnes, K. R. Howse, P. J. Welbank, and P. J. Taylor. 1974. Root and shoot growth of semi-dwarf and taller winter wheats. Ann. Appl. Biol. 77:129-144.

9. Norstadt, F. A., and T. M. McCalla. 1971. Effects of patulin on wheat grown to maturity. Soil Sci. 111:236-243.

10. Smika, D. E., and G. A. Wicks. 1968. Soil water storage during fallow in the Central Great Plains as infuenced by tillage with herbicide treatments. Soil Sci. Soc. Am. Proc. 32:591-595.

11. Taylor, H. M. 1971. Soil conditions as they affect plant establishment, root development, and yield. (F) Effects of soil strength on seedling emergence, root growth, and crop yield. p. 292-305. In K. K. Barnes (ed.) Compaction of agricultural soils. Am. Soc. Agric. Eng., St. Joseph, Mich.

12. - , and H. R. Gardner. 1963. Penetration of cotton seedling taproots as influenced by bulk density, moisture content, and strength of soil. Soil Sci. 96:153-156.

13. Wicks, G. A., and D. E. Smika. 1973. Chemical fallow in a winter wheat-fallow rotation. Weed Sci. 21:97-102. 